\title{
New Wave of Businesses: Brick to Click Approach in Malaysia
}

\author{
Nur Afiqah Mohammad Ishak ${ }^{1 *}$, Nurazariah Binti Abidin ${ }^{2}$, Jegatheesan Rajadurai ${ }^{3}$ \\ ${ }^{12}{ }^{3}$ Universiti Tenaga Nasional, Kampus Sultan Haji Ahmad Shah, Pahang \\ *Corresponding author E-mail: afiqah.mohammad3@gmail.com
}

\begin{abstract}
Having been born into a technologically advanced, wireless internet society, today's younger generation or the Millennial, is in a better position to be nurtured as the new age online businesses. They are well educated, self absorbed, have a strong sense of independence and highly motivated toward their perception of success. As such, the Millennial generation rushes forward with their marketing strategies to start businesses using social media to reach out their existing and potential consumers. While there have been numerous studies about traditional businesses, there has been little academic research focused on Millennial and which skills needed to become online businesses This paper proposed to measure the association between social media analytical skills and online businesses competencies within the Millennial generation. A questionnaire was used whose respondents were 100 online businesses among Millennial. It is hoped that this study will significantly contribute to a higher success rate in new start ups of online businesses for the Millennial generation. This study will not only enable for further advance the knowledge of Millennial but also to identify key aspects of online businesses competency in digital technologies.
\end{abstract}

Keywords: Digital technologies, Millennial generation; online businesses, online businesses competency, social media analytic skills.

\section{Introduction}

Digital technologies have also challenged existing business models and continue to do so. One of the key driving forces of it is the capacity of innovation and the consumerization of information technology certainly also plays a role. Digital business is about the stage that been seen in many maturity models (in marketing, ICT, social, business, etc), the converged or fully connected/integrated stage. From a sheer technology perspective it goes beyond the famous third platform and the evolutions we are witnessing today: cloud computing, the Internet of Things, mobile, Big Data, etc. By 2020, Malaysia aspires to be an advanced nation on many levels. However, it is more than about becoming an advanced economy, it is also about building a helpful and inclusive country that has ethics and morality and is truly integrated and united. The Eleventh Malaysia Plan, 2016-2020, is the next critical step in Malaysia's journey to becoming an advanced nation that is inclusive and sustainable [1]. For the young generations, who are the nation's hope and most valuable asset, the Government will realize this cohort's potential through capacity building, education, skills training, entrepreneurship, sports and volunteerism through the implementation of the new National Youth Policy[2,3]. The increasing rate of internet users, online spending and adopting of new technologies are the key drivers for the development of ECommerce in Malaysia. Government initiatives for the development of IT infrastructure and E-Commerce have shown a positive feedback from the businesses all over the [4]. There are many barriers to starting and operating new businesses and, similar to previous generations, the Millennial generation is facing these challenges. The Millennial generation is those born between 1980 and 2000. The 21st Century is the era of the digital economy because in this century everyone will own at least one smartphone [5]. Gradually they will become more ubiquitous, essential and sought after by consumers [6]. Access to digital networks and the services they provide are significant features of the 21st Century [7]. The exponential development in the digital economy is an oftcited phenomenon. The other oft-cited phenomenon is green entrepreneurship and online access. Businesses look for opportunities in the field and convert these opportunities into a business. A successful entrepreneur needs to exhibit several qualities such as planning, controlling, innovation, risk taking and decisionmaking. Moreover, the entrepreneur needs to learn entrepreneurial skills such as personal skills, technical skills and managerial skills. In the last decades, the development and use of technology, innovation and the digital world within a business is now described as online business. The new type of entrepreneur goes by the title of online businesses which is a combination of digital business, green business and the business itself [8]. As this development becomes more common, the issue of how starting a digital endeavor differs from starting a traditional endeavor grows more important; as does finding solutions to the problems specific to the digital enterprise. Although previous study have devoted considerable effort in identifying characteristics, traits, values, affective states and cognitive styles that are associated with online businesses but the particular competencies that are most critical remain elusive [9]. Businesses and managers contemplating new digital ventures need to understand the opportunities and hazards unique to online businesses. The lack of experience and skill on the part of the initiator are the most common reasons a new start up.

\section{Literature review}

\subsection{Online Businesses}

Online business also referred to as e-business, is any kind of business activity that happens online (over the internet).A business owner who does any, or all, of their business using the internet, is 
running an online business. Running an online business can include buying and selling online, and providing an online service [10]. A wide variety of businesses can be found online, in many different industries. Anyone can start an online business. If you have a unique product or idea, you can find a way to sell or trade it online. It's just like a traditional 'bricks-and-mortar' business, except your office or shop is online, so you have to decide how it will look and appeal to customers. Online business highlights the scope for the emergence of a new digital divide. The digital divide is gradually moving to one of affordable, reliable, safe and highspeed access to digital technologies, and ability to use and exploit the market to create new opportunities. In Malaysia, 53,285 online businesses have been registered with the Companies Commission of Malaysia (SSM)and the biggest online businesses such as Lazada, 11th Street, Zalora, and eBay [11]. Unexpectedly, many businesses are still not using technologies to their full potential due to a lack of skills, vision or regulatory barriers. As businesses, the Millennial generation needs to have specific traits that will help to build up their empires successfully. The Millennial generation needs to be professional in dealing with customers, persistent as the firm grows and be good planners $[6,12]$. There are many challenges from both external and internal sources that an businesses will need to overcome for the business to develop. Businesses play an important role in the economy. They contribute both on a large and small scale to the growth of industries in the country and therefore should not be ignored by the government.

\subsection{Challenges of Online Businesses}

The main issues for online businesses include skills, infrastructure and various aspects of the business setting. In many parts of the world, access to affordable, reliable, high-speed broadband infrastructure is still a problem, including in parts of some developed countries [13]. These factors are not just matters of concern terms of entrepreneurship, they are even more important in the fast changing and fast moving digital world for start upon online businesses, smaller and newer companies, that are highly innovative and therefore riskier [14]. Invigorating the business environment includes addressing issues related to entry and exit barriers, business creation and closure, data and privacy and security regulation, bankruptcy regulation and legislation, access to finance, market fragmentation especially for online, ICT provide services and a perceived policy bias towards larger firms $[15,16]$. Inadequacy in all of these areas causes friction and costly regulatory ambiguity for digital entrepreneurs. There are also some differences in the issues facing online businesses, and entrepreneurs more generally. For example, many online businesses are 'born global' on the Internet or have the ability to grow across borders very quickly [17]. There are some major differences between traditional businesses and online businesses. For example, how do they market the product itself whether goods or a services? An approach to online businesses needs to consider a few questions such as where do online businesses come from? What are the factors can motivate the online businesses? How do they reach the point to launch a new endeavour? These questions can be answered by analysing the common traits of successful online businesses $[18,19,20]$. The traits usually associated with an ecopreneur include innovation, responsibility-seeking and decision making, a desire for independence, ambition, self-confidence, power seeking, moderate risk taking and having personal value orientation [21]. Focusing on customer needs has long been the mantra of the marketing profession. The Internet is a fundamental technology advance on a huge scale because it presents no obvious negative externalities and is likely to continue to reshape all aspects of business.

\subsection{The Qualities of Online Businesses}

Online businesses are the ones who will take risks in terms of success or failure of a new business. They will persevere with a new idea until it works and direct all their resources to making the process a success. The fear of failing always looms but motivated by ambition and the desire to succeed, the entrepreneur sees the need in completing a project. Qualities are really important for online businesses because the issues are key to successful online businesses [22]. The qualities including the ability to identify the talent that is required, recruiting that talent (including across borders), to having the skill to identify new technology-enabled business opportunities and bringing them to fruition, either as a new venture, or by transforming existing business models, digital transformations, and even the successful conceptualization and implementation of most information technology projects [15]. Business leaders and entrepreneurs need to possess a level of technological awareness that allows them to identify new technologies that will transform and shape their business models to do new things, or do things differently and to develop new products and services. One of the qualities the online businesses need to have is social media analytical skills [23]. The growth of online business makes access to knowledge virtually ubiquitous and develops social media analytical skills. It helps online businesses to exploit knowledge and opportunities for innovation, growth and competitiveness [24].

\subsubsection{Social Media Analytic}

Social media analytics is the practice of gathering data from social media websites and analyzing that data using social media analytics tools to make business decisions. The most common use of social media analytics is to mine customer sentiment analysis to support marketing and customer service activities. Customer sentiment analysis or opinion mining is a processing system for tracking the mood of the public about a particular product. It can help online businesses evaluate the success of an ad campaign or new product launch, determine which versions of a product or service are popular and identify which demographics like or dislike particular product features. Online businesses also can analysis of the huge volume of social media data has many applications such as collective behavior sensing and monitoring, online advertisement, opinion mining, and etc. Social media data distinguishes itself from other kind of data, it consists of both structured and unstructured data [25], For example, the user profile is usually structured or semi structured. However, the content of pieces of information is usually unstructured. A social media service may continuously append pieces of information from users to the backend database in high speed because socio media data is dynamic. Meanwhile, analytical queries over the data may specify conditions on the time dimension. The temporal attribute gives hints on caching. Many systems are used for management of social media data. Hadoop, the open-source clone of Google File System and MapReduce programming paradigm, is often used for storage of social media data [26]. With these tools, online businesses can listen to consumers on Facebook, Twitter, blogs, forums and other ubiquitous social media platforms for posts and chat about products, services, events and other objects of business concern. The qualities to react to events in the physical world in an automatic, speedy and informed manner not only opens up new opportunities for dealing with complex or critical situations but also enables a wide range of business processes to be optimised. The concurrent interpretation of data from the physical world will most likely lead to the introduction of various new business services and may deliver significant economic and social benefits.

\section{Hypothesis}

The following hypothesis is proposed based on the literature:

$\mathrm{H}^{1}$ : There is a significant relationship between social media analytic skills and online businesses competency 


\section{Method}

For this preliminary research study, a questionnaire based survey was used. The survey form is self report by the Millennial generation who do online business. The list of Millennial doing online business obtained in Company Commission of Malaysia's website [27]. A systematic random sampling technique was used to select the respondents for this study. The total number of questionnaires distributed was 150 , however, only 100 were returned making the response rate for this study 67\%. Questionnaires for this study consisted of three sections. The first part of this study, asked questions about respondent demographic information, while the second section consisted of questions about online businesses' qualities. Section three consisted of questions about online businesses competencies. All items used in the analysis were adapted from the existing literatures. A five point Likert Scale was used in this study. Data analysis employed (PLS-SEM) version 3.0 using double stages methodology by Anderson and Gerbing (1988) [28] namely the measurement and structural model analysis. The criteria and procedures proposed in the literature by Henselerer al (2009) [29] and Hair, Sarstedt, Ringle, et al. (2012) [30,31] were also included in the evaluation of the results.

\section{Findings}

\subsection{Respondent Profile}

This study was dominated by $76(76 \%)$ female doing online business. Most of the respondents were Malay 77 (77\%) and the majority were aged 22 years to 26 years. Most of the entrepreneurs had already run businesses for between 2 and 5 years and they had not registered for the Companies Commissions of Malaysia.

Table 1: Respondent demographic profile

\begin{tabular}{|c|c|c|c|}
\hline Criteria & Category & Number & Percentage \\
\hline \multirow{2}{*}{ Gender } & Male & 24 & 24 \\
\hline & Female & 76 & 76 \\
\hline \multirow{3}{*}{ Race } & Malay & 77 & 77 \\
\hline & Chinese & 20 & 20 \\
\hline & Indian & 3 & 3 \\
\hline \multirow{4}{*}{ Age Group } & $17-21$ & 22 & 22 \\
\hline & $22-26$ & 49 & 49 \\
\hline & $27-31$ & 12 & 12 \\
\hline & $32-36$ & 17 & 17 \\
\hline \multirow{7}{*}{ Education Level } & Phd & 6 & 6 \\
\hline & Master & 6 & 6 \\
\hline & Bachelor Degree & 58 & 58 \\
\hline & Diploma & 3 & 3 \\
\hline & Foundation & 3 & 3 \\
\hline & STPM & 9 & 9 \\
\hline & SPM & 15 & 15 \\
\hline \multirow{4}{*}{$\begin{array}{l}\text { Years of doing } \\
\text { online business }\end{array}$} & Less than 1 year & 36 & 36 \\
\hline & $2-5$ years & 52 & 52 \\
\hline & 6-9 years & 12 & 12 \\
\hline & More than 9 years & - & - \\
\hline \multirow{2}{*}{ Register SSM } & Yes & 38 & 38 \\
\hline & No & 62 & 62 \\
\hline
\end{tabular}

\subsection{Measurement Model}

First the analysis of loading and cross loadings was done to assess if there were any problems with any items used in this study. As suggested by Garson (2007) [32], all factor loadings with cut off value less than 0.6 were deleted. In this study, only 2 items were deleted, SM6 and OB4 because the loading was less than 0.6. To evaluate the scales reliability, composite reliability (CR) and Cronbach's Alpha were utilised. Composite reliability value ranged from 0.955 to 0.965 which is more than 0.6 and indicated that they had a good construct [32]. Construct validity was confirmed through convergent and discriminant validity. Construct validity is used to find out how well the developed instrument measures a particular construct. The convergent validity is assessed through the AVE. According to Spreng and Mackoy (1996) [32], the AVE value for the variables must be near or greater than 0.5 . As in Table 3 below, the AVE value ranged from 0.657 to 0.663 , hence all the AVE values were accepted. However, if the AVE value is less than 0.5 and the composite reliability is higher than 0.6 , the convergent validity of the construct is still acceptable.

Table 2: Outer Loading/Cross Loading

\begin{tabular}{|c|c|c|}
\hline Construct & $\begin{array}{c}\text { Social media analytic } \\
\text { skills }\end{array}$ & $\begin{array}{l}\text { Online businesses compe- } \\
\text { tency }\end{array}$ \\
\hline SM1 & 0.747 & \\
\hline SM2 & 0.748 & \\
\hline SM3 & 0.845 & \\
\hline SM4 & 0.82 & \\
\hline SM5 & 0.846 & \\
\hline SM7 & 0.806 & \\
\hline SM8 & 0.805 & \\
\hline SM9 & 0.82 & \\
\hline SM10 & 0.841 & \\
\hline SM11 & 0.831 & \\
\hline SM12 & 0.804 & \\
\hline OB1 & & 0.797 \\
\hline OB2 & & 0.843 \\
\hline OB3 & & 0.834 \\
\hline OB5 & & 0.773 \\
\hline OB6 & & 0.837 \\
\hline OB7 & & 0.894 \\
\hline OB8 & & 0.857 \\
\hline OB9 & & 0.61 \\
\hline OB10 & & 0.902 \\
\hline OB11 & & 0.918 \\
\hline OB12 & & 0.839 \\
\hline OB13 & & 0.82 \\
\hline OB14 & & 0.747 \\
\hline OB15 & & 0.668 \\
\hline OB12 & & 0.839 \\
\hline OB13 & & 0.82 \\
\hline OB14 & & 0.747 \\
\hline OB15 & & 0.668 \\
\hline
\end{tabular}

*Note: $\mathbf{S M}=$ Social media analytic skills, $\boldsymbol{O B}=$ Online businesses competency

Next, to confirm the discriminant validity Fornell and Laker's (1981) method was used [34]. Contended that later is satisfied if its independent variance is higher than shared value with other constructs as evident in Table 3. Since all square roots of the AVEs are higher compared to all inter-construct correlations, the discriminant validity was confirmed [31].

Table 3: Result of reliability, convergent validity, AVE and discriminant validity analysis

\begin{tabular}{|c|c|c|c|c|c|}
\hline & $\begin{array}{c}\text { Cronbach's } \\
\text { Alpha }\end{array}$ & $\begin{array}{c}\text { Composite } \\
\text { Reliability }\end{array}$ & $\begin{array}{c}\text { Average } \\
\text { Variance } \\
\text { Extracted } \\
\text { (AVE) }\end{array}$ & 1 & $\mathbf{2}$ \\
\hline $\begin{array}{c}\text { 1 Social } \\
\text { media ana- } \\
\text { lytic skills }\end{array}$ & 0.948 & 0.955 & 0.657 & 0.811 & 0.811 \\
\hline $\begin{array}{c}\text { 2 Online } \\
\text { Businesses } \\
\text { Competency }\end{array}$ & 0.96 & & 0.965 & 0.663 & \\
\hline
\end{tabular}

\subsection{Structural Model}

When adopting PLS-SEM, the model is analysed on predictive relevance and statistical significance as per Hair et al. (2011) [31]. 


\subsubsection{Significance and Predictive Relevance of the Struc- tural Models}

To generate the outcome for the path coefficients significance levels through $\mathrm{t}$ statistics and predictive relevance, a bootstrapping procedure is used as suggested by Vinzi et al (2010) [35]. The results, as presented in Table 4 , indicated a strong connection between variables with a t-value of 21.899 , therefore the hypothesis proposed for this study is accepted. Figure 1 below illustrated the path coefficient model for this study. As presented in Table 4 below, the $\mathrm{R}^{2}$ value of 0.534 showed that the construct explained online businesses competency having a substantial relevance $\left(Q^{2}\right)$. This was done through a blindfolding procedure. Generally, $\mathrm{Q}^{2}$ values must be greater than 0 in order to have a predictive relevance. Therefore, the model is regarded as appropriate.

\begin{tabular}{|l|l|l|l|l|l|l|}
\multicolumn{2}{|c|}{ Table 4: Bootstrapping result } \\
\hline & $\begin{array}{l}\text { Stan- } \\
\text { dard } \\
\text { data }\end{array}$ & $\begin{array}{l}\text { Stan- } \\
\text { dard } \\
\text { Error }\end{array}$ & $\begin{array}{l}\text { T Sta- } \\
\text { tistics }\end{array}$ & $\begin{array}{l}\text { Deci- } \\
\text { sion }\end{array}$ & $\mathbf{R}^{2}$ & $\mathbf{Q}^{\mathbf{2}}$ \\
\hline $\begin{array}{l}\text { Social } \\
\text { media } \\
\text { analytic } \\
\text { skills -> } \\
\text { Online } \\
\text { Businesses } \\
\text { compe- } \\
\text { tency }\end{array}$ & 0.731 & 0.033 & $\begin{array}{l}21.899^{*} \\
*\end{array}$ & $\begin{array}{l}\text { Ac- } \\
\text { cepted }\end{array}$ & $\begin{array}{l}0.53 \\
4\end{array}$ & 0.31 \\
\hline
\end{tabular}

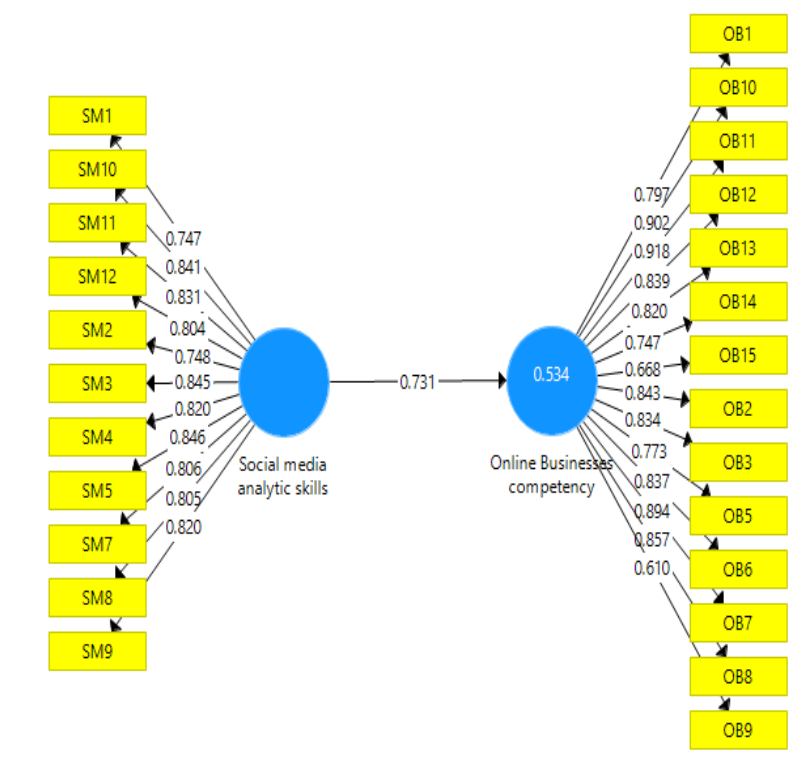

Note: $* p<0.05, * * p<0.01$

Fig. 1: Path Coefficient model

\section{Conclusion}

The most important challenges faced by online businessess include developing the vision and business idea, raising capital for the startup, lack of support, a negative mindset and lack of marketing strategies. These challenges need to be overcome in order to conduct an efficient business. Digital technologies offer remarkable growth opportunities but the entrepreneurs need to fully unlock these technologies full economic potential as the basis of their new businesses and e-commerce grow thin the for conclusions. However, to enable online businesses to maximise the benefits that access to the infrastructure can offer, the role of policy makers in creating the right conditions for growth of new digital business models, products and services becomes ever more important. Enabling online businesses in developing countries is especially important as this allows for the creation of new markets, the development of existing markets and entry into global value chains. Skills, infrastructure, financial inclusion and market access appear to be the enabling factors policy makers in these countries should focus on. The growth of online platforms that match demand and supply to the task also offers increasing opportunities for people to offer their services regardless of their location. These tasks extent the skills spectrum from low to high-end skills, and can be the first step into building a broader and more experienced skills base to allow new opportunities for countries to move up the value chain and increase local content in international supply chains. The online businesses need to have social media analytical skills to identify the sentiment of the market. The implication from the finding show that, social media analytic skills is important because it will enhance future online businesses the way they operate their business. However, further research needs to be conducted in order to enhance this study.

\section{Acknowledgement}

This research wishes to acknowledge the Ministry of Higher Education for the fund granted through the Fundamental Research Grant Scheme FRGS/1/2016/SS03/UNITEN/02/3.

\section{References}

[1] Percetakan Nasional Malaysia Berhad (2015). Speech by the Prime Minister in the Dewan Rakyat. RMK11_Speech, pp. 1- 40.

[2] Percetakan Nasional Malaysia Berhad. (2015). Eleventh Malaysia Plan: 2016-2020 Anchoring Growth on People, pp. 1-372

[3] The Parliamentary Secretariat for Research, Innovation, Youth and Sport (2015). National Youth Policy Towards 2020-A shared vision for the future, pp. 1-26.

[4] Ali, K. (2002). E-Commerce in Malaysia, the perceived benefits. Journal of economics and social sciences, 2(3).

[5] K. Langan (2012). Training Millennials : A practical and theoretical approach. Reference Services Review, 40 (1), 24-48.

[6] A. Lenhart, K. Purcell, A. Smith \& K. Zickuhr (2010). Social Media \& Mobile Internet Use among Teens and Young Adults. Millennials. PEI: Pew internet \& American life project.

[7] S. Lyons \& L. Kuron (2014). Generational differences in the workplace: A review of the evidence and directions for future re-search. Journal of Organizational Behavior, 35(1), 139-157.

[8] A. Aghelie, S. Sorooshian \& A. Noor Azlinna (2016). Research gap in sustainopreneurship. Indian Journal of Science and Technology, 9(12), 1-6

[9] Leong, C., Pan, S. L., \& Liu, J. (2016). Digital Entrepreneurship of Born Digital and Grown Digital Firms: Comparing the Effectuation Process of Yihaodian and Suning.

[10] Abd. Mukti, N. (2000). Barriers to putting businesses on the Internet in Malaysia. The Electronic Journal of Information Systems in Developing Countries, 2(1), 1-6.

[11] 53285 online businesses registered with SSM as of July 10 (2017, August 1). TheSun. Retrieved from: http://www.thesundaily.my/news/2017/08/01/53285-onlinebusinesses-registered-ssm-july-10

[12] Intuit Canada (2013). Startup Generation: How millennials are remaking the Canadian economy. Retrieved from: http://blog.intuit.ca

[13] Ulsch, M. (2014).Cyber Threat!: How to Manage the Growing Risk of Cyber Attacks. John Wiley \& Sons.

[14] Afzaal H. Seyal Md. Mahbubur Rahim Mohd. Noah A. Rahman (2017). An Empirical Investigation of Use of Information Technology among Small and Medium Business Organizations: A Bruneian Scenario. The Electronic Journal Of Information Systems In Developing Countries, 2(7), 1-17

[15] Bogdanowicz, M. (2015). Digital Entrepreneurship Barriers and Drivers. Retrieved from: https://core.ac.uk/download/pdf/38631774.pdf

[16] E. Asliturk, A. Cameron \& S. Faisal (2016). Skills In The Digital Economy. Information And Communications Technology Council (ICTC).

[17] Markova, J. Perry \& S.M. Farmer (2011). It's all about the data: Challenges and solution in the study of nascent entrepreneurs. Journal of Development Entrepreneurship, 16 (2), 169-198.

[18] Moulson, N. D. R. (2015). How millennial generation entrepreneurs use mentors to improve business performance. 
[19] Onstenk, J. (2003). Entrepreneurship and vocational education, European Educational Research Journal, 2 (1), 74-89.

[20] Smith, W. L., Schallenkamp, K., \& Eichholz, D. E. (2006). Entrepreneurial skills assessment: an exploratory study. International Journal of Management and Enterprise Development, 4(2), 179201.

[21] Gibbs, D. (2009). Sustainability entrepreneurs, ecopreneurs and the development of a sustainable economy. Greener Management International, 55, 63-78

[22] Currin, E. (2012). Businesses Going Green: An Analysis of the Factors that Motivate Firms to Adopt Environmentally Friendly Practices.6, 35-50.

[23] Yallapragada, R. R., \& Bhuiyan, M. (2011). Small business entrepreneurships In The United States. Journal of Applied Business Research, 27(6), 117-122.

[24] Z. Papulova \& M. Mokros (2007). Importance of Managerial Skills and Knowledge in Management for Small Entrepreneurs. E- leader $1-8$.

[25] De Sandes, E. F., Weigang, L., \& de Melo, A. C. M. (2012). Logical model of relationship for online social networks and performance optimizing of queries. International Conference on Web Information Systems Engineering, 726-736.

[26] Ghemawat S., Gobioff, H. and Leung, S.T. (2003) The Google file system, In Proc. of the 19th ACM SOSP, Bolton Landing, NY, USA. Retrieved from: http://labs.google.com/papers/gfs.html

[27] Official portal of Companies Commission of Malaysia (2016, December 4). Retrieved from: http://www.ssm.com.my/en

[28] Anderson, J. C., \& Gerbing, D. W. (1988). Structural equation modeling in practice: A review and recommended two-step approach. Psychological bulletin, 103(3), 411.

[29] Henseler, J., Ringle, C. M., \& Sarstedt, M. (2015). A new criterion for assessing discriminant validity in variance-based structural equation modelling. Journal of the Academy of Marketing Science, 43(1), 115-135.

[30] Hair Jr, J. F., Sarstedt, M., Hopkins, L., \& Kuppelwieser, V. G. (2014). Partial least squares structural equation modeling (PLSSEM): An emerging tool in business research. European Business Review, 26(2), 106-121.

[31] Hair, J. F., Ringle, C. M., \& Sarstedt, M. (2011). PIS-Sem: Indeed a Silver Bullet. The Journal of Marketing Theory and Practice, 19(2), 139-152.

[32] Garson, G.D. (2007) Factor analysis.[oline]. Retrieved from: http://www2.chass.ncsu.edu/garson/pa765/factor.htm [16 March 2008].

[33] Fornell C, Larcker DF. Evaluating structural model with unobserved variables and measurement errors. Journal of Marketing Research, 1981; 18 (1): 39-50

[34] Spreng, R. A., \& Mackoy, R. D. (1996). An empirical examination of a model of perceived service quality and satisfaction. Journal of retailing, 72(2), 201-214.

[35] Vinzi, V. E., Trinchera, L., \& Amato, S. (2010). PLS path modeling: from foundations to recent developments and open issues for model assessment and improvement. In Handbook of partial least squares (pp. 47-82). Springer Berlin Heidelberg. 